\title{
Analysis of the number of sensilla on the labrum and the diet of grasshoppers belonging to the family Pamphagidae (Orthoptera)
}

\author{
Naima BENKENANA ${ }^{1}$, Abboud HARRAT ${ }^{1}$ and DANIEl PETIT $^{2}$ \\ ${ }^{1}$ Laboratoire de Biosystématique et Ecologie des Arthropodes, Université Mentouri, Constantine, route d'Aïn-El-Bey-25000, \\ Constantine, Algérie; e-mail: naima_benkenana@yahoo.fr, abboud52@yahoo.fr \\ ${ }^{2}$ UMR 1061 INRA, Université de Limoges, 123, av. A. Thomas, 87060 Limoges Cedex, France; e-mail: daniel.petit@unilim.fr
}

Key words. Orthoptera, Pamphagidae, diet, labrum sensilla, Algeria

\begin{abstract}
We studied the diet of 10 species of grasshopper belonging to the family Pamphagidae over a period of 3 years at 6 localities in North Eastern Algeria. The species of plants consumed by the grasshoppers was determined by comparing slide mounted specimens of the pieces of plant epidermis in their faeces with those in a reference collection of identified plants collected from the same localities. The percentages of occurrence of the different species of plants in the faeces of the grasshoppers were not related to the abundance of the plants at the sites studied. All the grasshoppers were polyphagous but differed in the percentage of Poaceae in their diets. The diet of Tmethis and Ocneridia contained a higher percentage of Poaceae than the other species and are considered to be ambivores. The three species in the Pamphagus gr. djelfensis complex differ in their diets but all tend to avoid consuming Poaceae and are categorized as forbivores. We also compared the frequency of occurrence of Fabaceae in the faeces and in the field and $O$. volxemii is the only species that avoided consuming this plant family. The number of sensilla on the labrum was also studied in both sexes of each species. Once one corrects for differences in the size of the labrum, the forbivores have higher numbers of sensilla in groups A1, A2 and A3 (but not A10) than the ambivores. The numbers of sensilla in the A10 group on the labrum of species of Pamphagidae is greater than on that of species of Acrididae, which are mainly graminivores and adapted to semi-arid conditions.
\end{abstract}

\section{INTRODUCTION}

The diet of grasshoppers depends on the habitat they occupy and the species. In this context mandible shape of grasshoppers has been studied since the 1940s (Isely, 1944) and more recently in Mediterranean species (Rizzo \& Massa, 1995). Their digestive capacity depends on the intracellular production of enzymes and the microbiome in their alimentary canal (Idowua et al., 2009). The sensilla on the antenna and mouth parts detect the secondary metabolites in the leaves of plants (Chapman \& Joern, 1990). In this work, we focus on the sensilla on the labrum of species belonging to the family Pamphagidae.

These sensilla are dome shaped, have a gustatory function and are distributed in well delimited areas on the epipharyngeal surface of the labrum, i.e. the structure covering an insect's mouth. Thomas (1966) defined four discrete groups of sensilla based on their position on the labrum: group A1 (proximal end), A2 (central part), A3 (distal part) and A10 (lateral part, at a level intermediate between the A1 and A2 groups). Several studies show there is a relationship between the number of sensilla on the labrum and the diet of grasshoppers. For example, monophagous grasshoppers, which feed on one or only a few species of plants, have fewer sensilla than oligophagous (feed on species of one plant family) or polyphagous (feed on species of several plant families) grasshoppers (Chapman \& Thomas, 1978). In contrast, El Ghadraoui et al. (2002) report that species of Dociostaurus (Acrididae, Gomphocerinae) have many more sensilla and a wider host range than other genera in the same subfamily which are mostly oligophagous. The present study investigates the number of sensilla and diet of a poorly known grasshopper family, the Pamphagidae, in Eastern Algeria.

Pamphagidae Burmeister, 1840, is a family of large roughly tegumented and mostly apterous geophilous grasshoppers, some genera of which in Algeria are long winged, such as Tmethis (Ihsan \& Donskoff, 1988). Occasionally, outbreaks are recorded for several species in this family as in other families (Benzara et al., 1993). Ocneridia volxemii is a serious pest of cereal crops grown on the Algerian high plateaus (Bounechada \& Doumandji, 2003). A more recent study by Ladrón de Guevara et al. (2009) reports outbreaks of two species of Acinipe in Castilla-La Mancha, Spain. Based on the recent phylogenies of Zhang et al. (2005) and information in Orthoptera Species File on line (Eades et al., 2011) this family includes 8 subfamilies.

In a previous study we recorded 16 species and described a new species belonging to the Pamphagus djelfensis complex (Benkenana et al., 2012) in Eastern Algeria, based on the revisions of Chopard (1943), Uvarov (1943), Descamps \& Mounassif, 1972), Biondi \& Massa (1995), Massa \& Cusimano (1979), Massa \& Biondi (1987), Massa \& Lo Verde (1990), Massa et al. (1993) and Massa (1992, 1996). In particular, we studied the distribution, climatic constraints and some aspects of the biology of each species. There is little information on the plants eaten by species of this family and to the best, of our knowledge there is only one study that of Bounechada and Doumandji (2003), which focused on Ocneridia volxemii. In Spain, Gangwere \& Morales-Agacino 
TABLE 1. Details of the sites sampled.

\begin{tabular}{|c|c|c|c|c|c|c|}
\hline Wilaya & Sites & $\begin{array}{l}\text { Altitude } \\
\text { (m) }\end{array}$ & $\begin{array}{l}\text { Geographic } \\
\text { coordinates }\end{array}$ & Bioclimate & $\begin{array}{l}\text { No. of species } \\
\text { and plant families } \\
\text { (in brackets) }\end{array}$ & $\begin{array}{l}\text { Dominant plant } \\
\text { families }(\%)\end{array}$ \\
\hline Skikda & Collo & 43 & $\begin{array}{c}36^{\circ} 53^{\prime} \mathrm{N} \\
6^{\circ} 54^{\prime} \mathrm{E}\end{array}$ & Humid & $\begin{array}{c}34 \\
(15)\end{array}$ & $\begin{array}{c}\text { 27.46 Poaceae } \\
\text { 24.51 Asteraceae } \\
\text { 08.63 Fabaceae } \\
\text { 04.59 Ranunculaceae }\end{array}$ \\
\hline Constantine & Tidisse & 660 & $\begin{array}{c}36^{\circ} 22^{\prime} \mathrm{N} \\
6^{\circ} 40^{\prime} \mathrm{E}\end{array}$ & $\begin{array}{l}\text { Semi-arid } \\
\text { with cold } \\
\text { winter }\end{array}$ & $\begin{array}{l}34 \\
(08)\end{array}$ & $\begin{array}{c}\text { 53.1 Poaceae } \\
\text { 43.7 Fabaceae } \\
\text { 05.2 Malvaceae }\end{array}$ \\
\hline \multirow[b]{2}{*}{ Oum-Elbouaghi } & $\begin{array}{l}\text { Oum- } \\
\text { Elbouaghi }\end{array}$ & 800 & $\begin{array}{c}35^{\circ} 52^{\prime} 39 \mathrm{~N} \\
7^{\circ} 06^{\prime} 49 \mathrm{E}\end{array}$ & Semi-arid & $\begin{array}{l}27 \\
(12)\end{array}$ & $\begin{array}{c}\text { 26.90 Poaceae } \\
\text { 26.60 Asteraceae } \\
\text { 03.20 Euphorbiaceae }\end{array}$ \\
\hline & Ain-Mlila & 794 & $\begin{array}{l}35^{\circ} 53^{\prime} \mathrm{N} \\
06^{\circ} 33^{\prime} \mathrm{E}\end{array}$ & Semi-arid & $\begin{array}{l}30 \\
(13)\end{array}$ & $\begin{array}{c}44.47 \text { Asteraceae } \\
\text { 14.00 Poaceae } \\
\text { 08.08 Lamiaceae } \\
\text { 06.06 Brassicaceae }\end{array}$ \\
\hline Batna & $\begin{array}{c}\text { Djerma } \\
\text { Belezma } \\
\text { National Park }\end{array}$ & 991 & $\begin{array}{c}35^{\circ} 9^{\prime} 47^{\prime \prime} \mathrm{N} \\
7^{\circ} 6^{\prime} 16^{\prime \prime} \mathrm{E}\end{array}$ & Semi-arid & $\begin{array}{l}45 \\
(21)\end{array}$ & $\begin{array}{c}\text { 27.86 Poaceae } \\
\text { 24.51 Asteraceae } \\
\text { 04.59 Ranunculaceae } \\
\text { 03.99 Fabaceae }\end{array}$ \\
\hline Khenchela & Babar & 1142 & $\begin{array}{l}35^{\circ} 32^{\prime} 40^{\prime \prime}- \\
35^{\circ} 37^{\prime} 46^{\prime \prime} \mathrm{N} \\
5^{\circ} 55^{\prime} 10^{\prime \prime}- \\
6^{\circ} 10^{\prime} 45^{\prime \prime} \mathrm{E}\end{array}$ & Semi-arid & $\begin{array}{l}27 \\
(10)\end{array}$ & $\begin{array}{c}\text { 36.00 Poaceae } \\
\text { 18.17 Asteraceae } \\
\text { 16.31 Fabaceae }\end{array}$ \\
\hline
\end{tabular}

(1973) studied 2 species (Acinipe sp. and Eucnerodes brunnerii), which they classified as forbivorous and dendrophagous, respectively.

In order to interpret the differences recorded in the diets, we determined the number of sensilla on the labrum, a topic well studied in Acrididae but not in Pamphagidae.

\section{MATERIAL AND METHODS}

\section{Study sites}

This study was carried out at 6 places in the Tellian Atlas in the North-Eastern part of Algeria: Collo, Constantine, Ain-Mlila, Oum-Elbouaghi, Batna and Khenchela (Table 1). The climates at these sites range from semi-arid to humid, and the altitudes range between $43 \mathrm{~m}$ a.s.l. at Collo, which is close to the Mediterranean coast, to $1142 \mathrm{~m}$ at Khenchela, with most places above $600 \mathrm{~m}$. We also studied a population of Prionotropis hystrix rhodanica, which inhabits pseudo-steppic vegetation in the réserve naturelle nationale de Coussoul at SaintMartin-de-Crau (Southern France, 4333'473"N, 452'493"E). Thanks to the kindness of A. Foucart (CIRAD, Montpellier), we were able to study the faeces of 10 individuals collected in 2002. The herbaceous flora there is very rich and the dominant plant species are as follows (Dutoit et al., 2011): Brachypodium retusum (20-70\%), Trifolium subterraneum (5-20\%) and Thymus vulgaris (3-7\%).

The flora was sampled between late March and April 2010. Samples of different species of plant were collected, dried and kept in a reference herbarium at the Laboratory of Biosystematics and Ecology of Arthropods (Mentouri University of Constantine). Each herbarium sheet indicates the date, where collected and identification based on the keys in Quézel \& Santa (1962-1963). The nomenclature was updated using TelaBotanica, a website available at the URL address http://www.tela-botanica.org. The percentages of each species at each place were determined using the transect method. The numbers of each species of plant were recorded along a $100 \mathrm{~m}$ rope stretched between two stakes. Depending on the place the numbers along five to ten transects were recorded and the distance between transects was at least $3 \mathrm{~m}$. The values recorded were used to calculate the total richness, Shannon index and mean percentages of Poaceae and Fabaceae in the flora.

\section{Reference collection of slides of the epidermis of the different plants}

For the study of the diet of Acridomorpha in the field it was necessary to be able to identify pieces of plant epidermis in their faeces, which was done by referring to a collection of slide mounts of the epidermis of the different plants present at each locality. From each herbarium specimen of the species of plant collected at each locality, we took a sample of epidermis following the technique used by Kara in 1996 and published in Ould Elhadj (2001). Briefly, a dry fragment of leaf was softened by placing it in water for one day. The epidermis was carefully removed from the underlying tissues using a sharp knife. To clear the pieces of epidermis they were placing in a $12 \%$ solution of bleach for a few minutes and then rinsed in distilled water. These specimens were then dehydrated by placing them first in $70 \%$ followed by $80 \%$ and finally $96 \%$ alcohol. The epidermal fragments were mounted in Canada balsam on a slide and covered with a cover slip and the slide was then labelled with the name of the plant, date and locality.

\section{Collection of faeces}

The grasshoppers collected were kept individually in plastic jars labelled with the name of the species, date and where collected. According to Launois-Luong (1975), one to two hours is sufficient for a grasshopper to empty its gut. Benhalima et al. (1984) note that the quickest emptying occurs at the beginning of the afternoon around 2 p.m. when it takes about $8 \mathrm{~h}$ for food to pass through the gut. In the case of Dociostaurus maroccanus, Bouanane (1993) in Ould Elhadj (2001) claims 

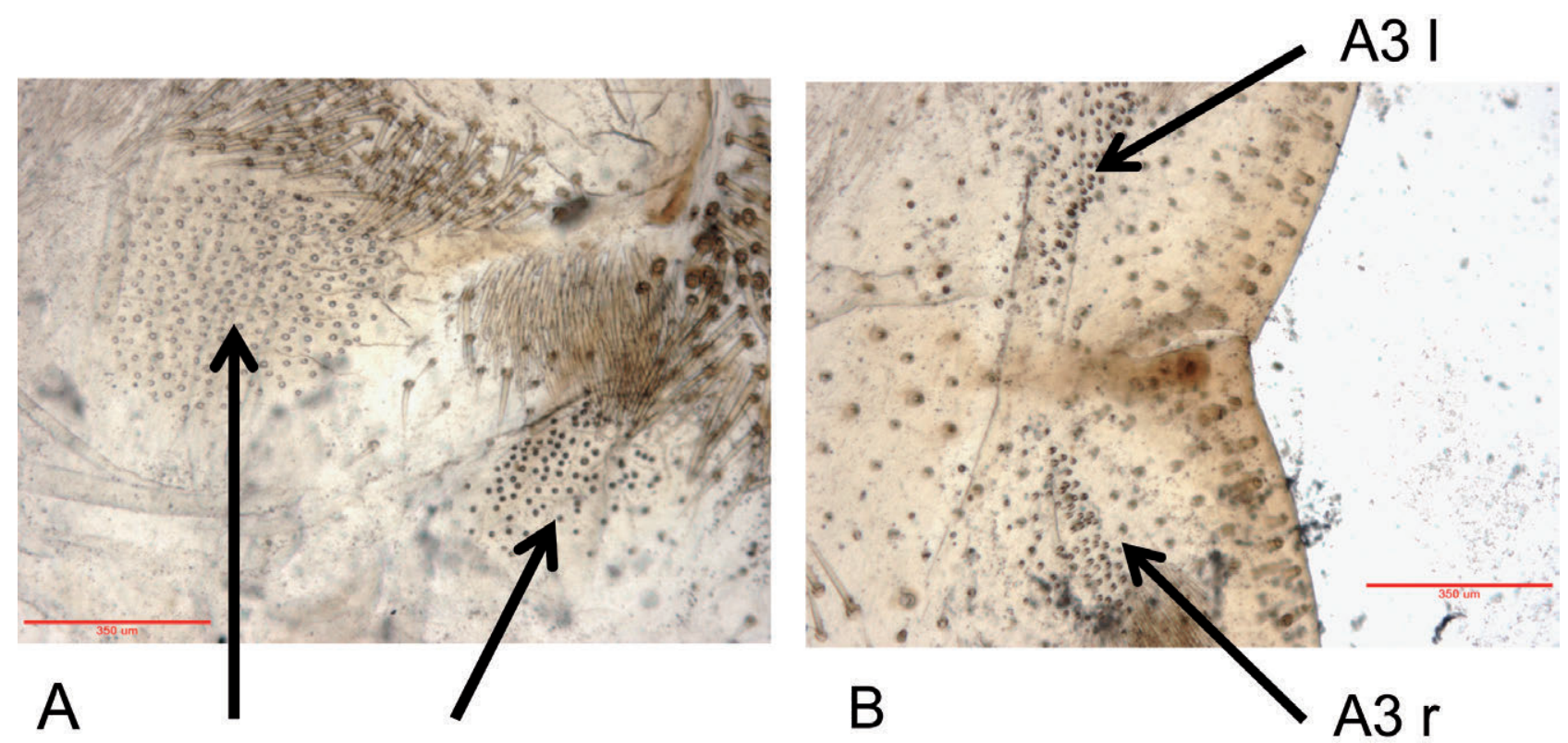

A1 A2
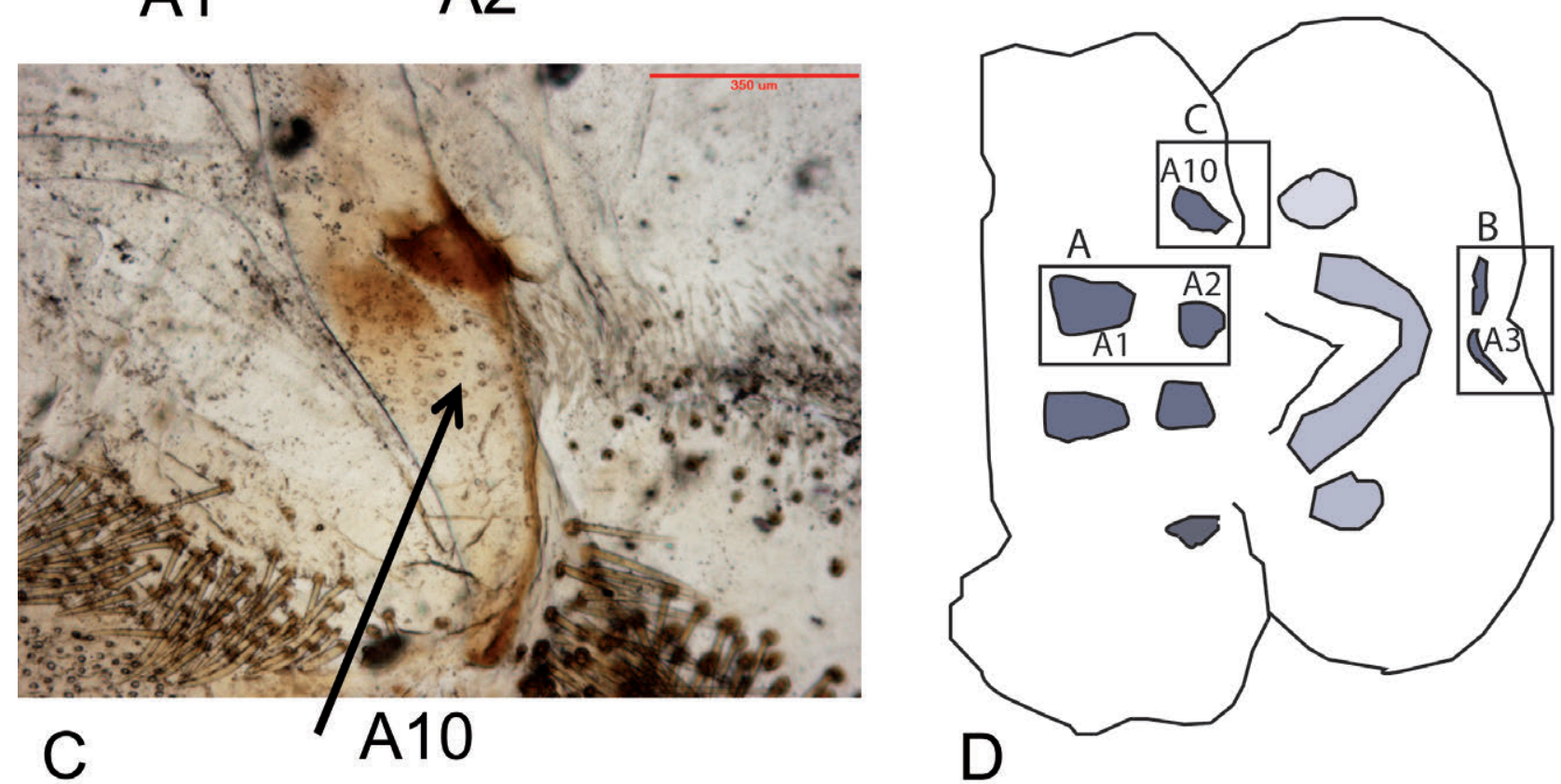

Fig. 1. Sensilla on the labrum of Pacinipe saharae (female). D - diagram of the distribution of the different groups of sensilla on the labrum; A - A1-A2 sensilla; B - A3 sensilla; C - A10 sensilla. Light grey areas: location of the sensory hairs that monitor the chemicals in the juice that exudes from crushed leaves. Pictures were taken using a DNI6000B microscope (Leica microsystems). Scale bar $=350 \mu \mathrm{m}$.

that $24 \mathrm{~h}$ is insufficient for all the contents of the digestive tube to be excreted as faeces. In the present work, faeces were collected over a period of $24 \mathrm{~h}$ post capture and stored in paper envelopes labelled with date, where the grasshopper was collected and the species, but not the sex.

The method used to examine the contents of the faeces was a modified version of that used by Launois-Luong (1975). First the faeces were softened by placing them in water for $24 \mathrm{~h}$ after which the soft pieces of epidermis were cleared by placing them in bleach for a few minutes. The next steps are identical to those used for examining the epidermis of plants. A slide preparation of each piece of epidermis was made and labelled with date, where the grasshopper was collected and species. Each piece of plant was identified by comparing it with specimens from known plants in the reference collection. We particularly focused on the shape and size of the cells and hairs, and presence of crystals. According to Butet (1985), the frequency of plant species $\mathrm{i}$ in faeces is calculated using the formula: $\mathrm{F}(\mathrm{i})=$ $\mathrm{ni} / \mathrm{N}$, where $\mathrm{ni}=$ number of faeces in which plant $\mathrm{i}$ is present, $\mathrm{N}$ $=$ total number of faeces examined.

These values were used to calculate the total number of species and Shannon index, and the mean percentages of Poaceae and Fabaceae. At three of the sites sampled, two or more grasshopper species coexisted and for these we compared richness and diversity of plant remains in their faeces using the boostrap test in PAST 2.14 (Hammer et al., 2001). The composition of plants consumed was compared within and between species collected at the same locality using an ANOSIM (Analysis of Simi- 
TABLE 2. Summary of the species richness and diversity of plants at the sites sampled and differences in these values recorded for the faeces. The numbers of specimens studied are in brackets. \% Poaceae at a site corresponds to their relative abundance and the percentage of this family in the faeces. The different letters correspond to significant differences based on the bootstrap test. $* *-p$ $<1 \%$; ** $-\mathrm{p}<0.1 \%$. The values in the last four columns are the differences between these values for the faeces of a species of grasshopper and those for the site sampled.

\begin{tabular}{|c|c|c|c|c|c|c|c|c|}
\hline $\begin{array}{l}\text { Sampling sites } \\
\text { and species }\end{array}$ & $\begin{array}{l}\text { Plant species } \\
\text { richness }\end{array}$ & $\begin{array}{l}\text { Plant diver- } \\
\text { sity Shannon } \\
\text { index }\end{array}$ & $\%$ Poaceae & $\%$ Fabaceae & $\begin{array}{l}\text { Diff in spe- } \\
\text { cies richness }\end{array}$ & $\begin{array}{l}\text { Diff in diver- } \\
\text { sity Shannon } \\
\text { index }\end{array}$ & $\begin{array}{c}\text { Diff in } \\
\% \text { Poaceae }\end{array}$ & $\begin{array}{l}\text { Diff in } \\
\text { \% Fabaceae }\end{array}$ \\
\hline Belezma & 45 & 2.88 & 27.86 & 3.99 & & & & \\
\hline P. auresianus (10) & $20 \mathrm{a}$ & $2.96 \mathrm{a} * * *$ & 3.33 & 23.33 & -25 & -0.058 & -24.53 & 19.34 \\
\hline P. batnensis (9) & $13 \mathrm{~b} * * *$ & $2.55 \mathrm{~b}$ & 4.55 & 13.64 & -32 & -0.411 & -23.31 & 9.65 \\
\hline P. djelfensis (8) & $15 b^{* *}$ & $2.82 \mathrm{a} * *$ & 9.52 & 28.57 & -30 & -0.239 & -18.34 & 24.58 \\
\hline Oum-Elbouaghi & 27 & 3.17 & 26.9 & 1 & & & & \\
\hline P. elephas (9) & 12 & 2.32 & 20.00 & 5.00 & -15 & -0.85 & -6.90 & 4.00 \\
\hline Collo & 34 & 3.32 & 27.46 & 8.63 & & & & \\
\hline P. cristatus $(8)$ & 8 & 1.93 & 6.67 & 6.67 & -26 & -1.386 & -20.79 & -1.96 \\
\hline Babar & 27 & 3.01 & 36 & 16.31 & & & & \\
\hline P. saharae (13) & 7 & 1.85 & 50 & 35 & -20 & -1.155 & 49.64 & 34.84 \\
\hline Tidisse & 34 & 1.72 & 53.10 & 43.7 & & & & \\
\hline O. volxemii (10) & $11 \mathrm{a} * * *$ & $2.14 \mathrm{a} * * *$ & 66.67 & 0.00 & -23 & 0.417 & 13.57 & -43.70 \\
\hline A. calabra (3) & $6 \mathrm{~b} * * *$ & $1.75 \mathrm{~b} * * *$ & 0 & 37.5 & -28 & 0.026 & -53.10 & -6.2 \\
\hline Ain-Mlila & 30 & 3.37 & 14 & 0 & & & & \\
\hline T. pulchr. (10) & $12 \mathrm{a}$ & $2.26 \mathrm{a}$ & 10 & 0 & -18 & -1.102 & 9.86 & 0.00 \\
\hline T. $\operatorname{cisti}(9)$ & $15 \mathrm{a}$ & $2.58 \mathrm{~b} * *$ & 21.74 & 0 & -15 & -0.781 & 21.60 & 0.00 \\
\hline
\end{tabular}

larity), a non parametric test based on a measure of similarity (Clarke, 1993), as in assemblage comparisons (Moussi et al., 2011). Here, the Bray-Curtis index was selected, and p-values were deduced from 10000 permutations.

To compare the diet of different species, it was necessary to take into account the composition of the flora at the sites sampled, as most species were collected in different areas. For each locality, we calculated the differences between the richness, diversity, percentages of Poaceae and Fabaceae between the sites sampled and the corresponding values for the faeces. A positive difference for Poaceae for example means that this family is preferentially consumed and a negative difference that it is avoided. These differences were analyzed using Principal Component Analysis in order to project the grasshopper species on to a plane structured by the direction of the variables, using PAST 2.14 (Hammer et al., 2001). The grouping of species was deduced using cluster analysis and Pearson's coefficient as a measure of distance. Each group corresponds to a particular type diet. The robustness of the clusters was estimated by a bootstrap technique with 1000 replicates.

To determine if an insect's consumption of a particular species of plant was based only on its abundance or whether it prefers or avoids eating this plant, we performed Spearman correlation tests using the values recorded at the sites and for the contents of the faeces, using PAST 2.14.

\section{Number of sensilla}

The number of sensilla on the labrum was determined using the technique of El Ghadraoui et al. (2002). Labrum of each grasshopper was removed under a stereomicroscope and immersed in a $50 \% \mathrm{KOH}$ solution for $1-6 \mathrm{~h}$ in order to clear the soft tissues, then rinsed in distilled water for $15 \mathrm{~min}$. The labrum was mounted in glycerol gelatine under a cover glass and observed under a Leica DNI6000B microscope.
It was easy to recognize the $\mathrm{A} 1, \mathrm{~A} 2, \mathrm{~A} 3$ and $\mathrm{A} 10$ groups of sensilla in the different species (Fig. 1). In the case of the A10 group, the sensilla may be absent in some species and either replaced by vestigial structures such as spines or a flat surface. Labrum width was measured and the numbers of sensilla in the different groups of sensilla (A1, A2, and A3 and A10) counted. The count of the number of sensilla is the sum of the numbers in each of the groups on both sides of the labrum.

For the comparison of numbers of sensilla among species, we removed the effect of labrum size by regression, as described in El Ghadraoui et al. (2002). Briefly, the regression of numbers of A1 sensilla (for example) on labrum width was used to calculate the residuals between observed and predicted numbers of A1 sensilla for a particular width of labrum. Regression analyses were performed using Microsoft Excel ${ }^{\mathrm{TM}}$. To determine the relationship between the number of sensilla and diet, ANOVAs were conducted using SYSTAT 7.0 (SPSS Inc.1997) with the residuals of the number of sensilla as variables and diet as groups.

\section{RESULTS}

The number of species of plants recorded at the six sites sampled (Table 1) varied between 27 and 45, and the number of families between 10 (Babar) and 21 (Belezma). Poaceae, Asteraceae and Fabaceae were the dominant plant families at the six sites.

\section{Diet of grasshoppers}

At the Belezma site, we compared the diets of three species of grasshopper belonging to the $P$. djelfensis complex. These species consume less Poaceae but more Fabaceae than one would expect based on the abundance of these families of plants at this site (Table 2). None of the correlations between the abundances of species of plants 
at a site and in the faeces of the grasshoppers were significant (Table 3). The comparison of the different species of grasshopper using ANOSIM revealed no difference in the species composition of the plants consumed $(\mathrm{p}>0.125)$, although that consumed by $P$. auresianus in terms of species richness and diversity was greatest $(\mathrm{p}<0.1 \%)$ when the results for P. batnensis were included.

At Oum-Elbouaghi, only P. elephas was recorded. The percentage of Fabaceae in its diet was greater than that recorded in the field, whereas for Poaceae it was about the same at this site. There was no correlation between the species composition of the plants in faeces and that in the field $(\mathrm{p}=9.4 \%)$.

At Collo, only P. cristatus was recorded and its faeces contain less Poaceae than expected, but about the same percentage of Fabaceae as present in the flora at this site. The lack of a preference of this species for certain food plants is indicated by a non-significant correlation between plant abundance in the field and in faeces ( $p=$ 0.86). Unexpectedly, one female was found consuming a leaf of a Ficus tree.

At Babar, Paracinipe saharae consumes much more Poaceae and Fabaceae than expected based on the percentage of these plants in the flora at this site. However, as for the above species, there was no correlation between the species composition of the plants recorded in the field and in faeces $(\mathrm{p}=0.61)$.

At Tidisse, Ocneridia volxemii and Acinipe calabra were recorded. $O$. volxemii consumed a greater number and diversity of plants than A. calabra ( $\mathrm{p}<0.1 \%$ ). Moreover, the ANOSIM revealed that the species composition of the plants consumed by these two species differed $(\mathrm{P}=0.076)$. This is mainly because Poaceae were preferred by $O$. volxemii and Fabaceae by A. calabra. In addition, there was no correlation between plant abundance in the field and in faeces for either species $(\mathrm{p}>$ $0.8)$.

At Ain-Mlila, two species of grasshopper were recorded: Tmethis pulchripennis and T. cisti. The species composition of plants in the faeces of $T$. cisti was more diverse $(\mathrm{p}<1 \%)$ than that recorded for $T$. pulchripennis, although the richness and composition $(p=0.43$ by ANOSIM test) were not significantly different. Both species consumed Poaceae, but there is no information on whether it would consume Fabaceae as this family of plants does not occur at this site. The species of plants consumed by both grasshoppers was dependent on the abundance of the plants ( $\mathrm{p}>0.6$, Spearman rho).

Brachypodium retusum (Poaceae) in the faeces of individuals of the French Coussoul population of $P$. hystrix rhodanica made up about $38 \%$ with the remainder mainly

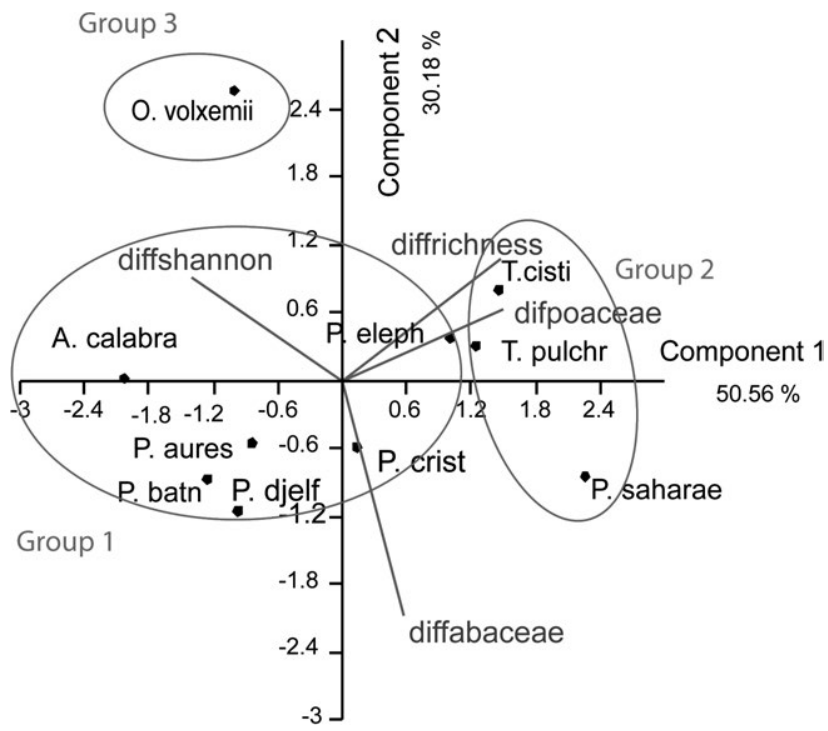

Fig. 2. Projection of species and variables on the plane defined by the 2 first axes of the PCA. The percentages of variance accounted for by the first 2 axes are indicated. diffshannon: difference between values in the diversity index for the flora at each of the sites and in faeces; diffrichness: difference between plant richness at each of the sites and in faeces; difpoaceae: difference between the relative abundance of Poaceae at each of the sites and in faeces; diffabaceae: difference between the relative abundance of Fabaceae at each of the sites and in faeces.

composed of five different dicotyledonous plants (between 5 and 16\%). It is concluded that its diet is diverse, but it is unknown whether it prefers certain plants as the abundance of the different plants was not recorded at this site.

The following comparison of the diet of each of the species collected in Algeria took into account the differences between the species composition of the plants in the field and in faeces in terms of richness and diversity of the total flora and percentage of Poaceae and Fabaceae. A PCA of the differences are presented in the projection in Fig. 2, which accounts for more than $80 \%$ of the total variance. It displays three groups of variables for differences: Richness, Shannon index and percentage of Fabaceae and Poaceae. The projections for Tmethis and $P$. saharae indicate they eat more Poaceae and greater number of species of plants. In contrast, all the species of Pamphagus and A. calabra consume less Poaceae than expected based on their availability in the field. $O$. volxemii is exceptional as it seems to avoid eating plants of the family Fabaceae. We tested the homogeneity of these three groups of grasshoppers using cluster analysis of the Pearson correlations between different variables. The hierarchical classification presented in Fig. 3 supports

TABLE 3. Spearman correlations between abundances of plant species at each of the sites sampled and in the faeces of the different species of grasshopper at those sites.

\begin{tabular}{lcccccccccc}
\hline & P. aures. & P. batnensis & P. djelfensis & P. elephas & P. cristatus & T. pulchr. & T. cisti & O. volxemii & A. calabra & P. saharae \\
\hline rho & -0.11 & 0.365 & -0.26 & 0.328 & 0.029 & -0.089 & -0.126 & -0.020 & -0.042 & -0.096 \\
$\mathrm{p}$ & 0.6316 & 0.2196 & 0.354 & 0.094 & 0.867 & 0.639 & 0.506 & 0.936 & 0.867 & 0.613 \\
\hline
\end{tabular}




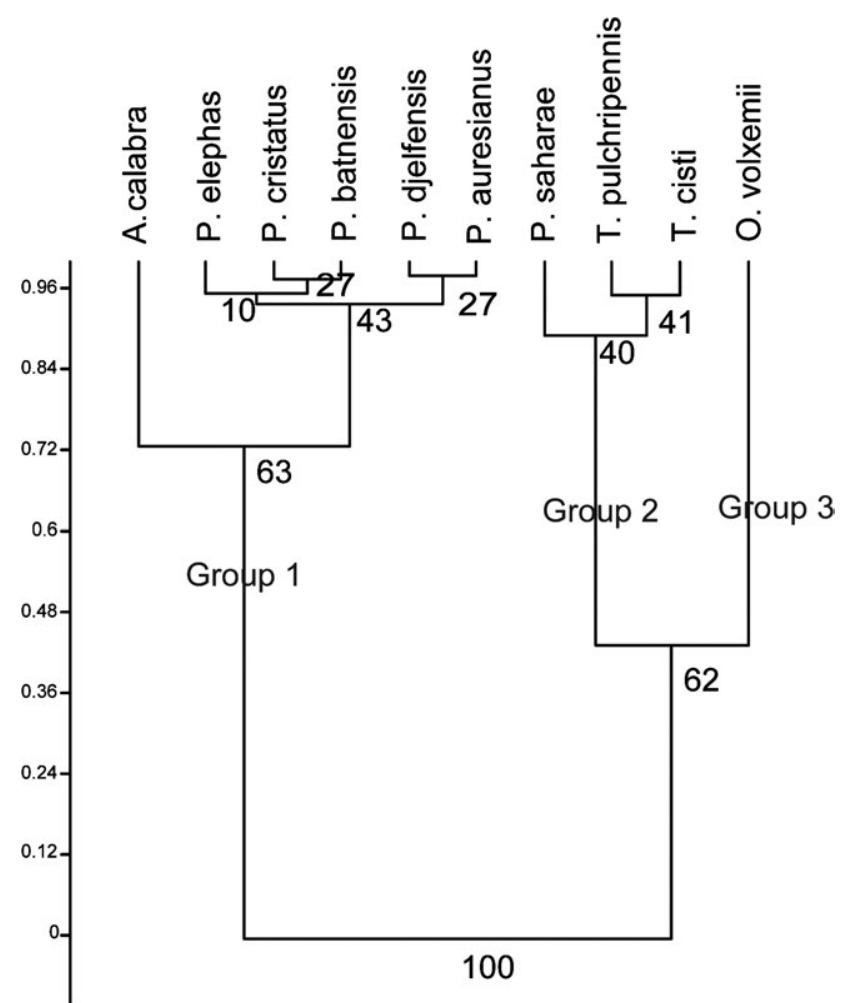

Fig. 3. Cluster analysis of species using Pearson correlation as distance measure. The vertical scale corresponds to correlation coefficient. The robustness of association is given by percentages based on 1000 bootstrap replicates.

previous observations that $P$. saharae is close to both of the species of Tmethis, as well as the common branch to Acinipe and all species of Pamphagus. O. volxemii is close to the group containing Tmethis and Paracinipe,

TABLE 4. The number of sensilla on the different parts of the labrum of the different species. L and 1 are the height and width of labrum, respectively. The numbers in brackets are the number of specimens studied.

\begin{tabular}{|c|c|c|c|c|c|c|}
\hline Species & $\mathrm{L}(\mathrm{mm})$ & $1(\mathrm{~mm})$ & A1 & A2 & A3 & A10 \\
\hline O. volxemii $\mathrm{F}(5)$ & 4.60 & 4.76 & 172.0 & 115.8 & 76.8 & 79.2 \\
\hline iii M (8) & & 2.89 & 147.6 & 81.4 & 58.3 & 66.8 \\
\hline P. auresianus $\mathrm{F}$ & & 7.53 & 408 & & 130.7 & 92.0 \\
\hline P. auresianus M (5) & & 5.67 & 356.0 & & 117.8 & 112.7 \\
\hline batnensis F (4) & & 6.95 & 435 & & & 105.8 \\
\hline P. bat & & 5.57 & 378 & & 112.5 & 75.7 \\
\hline$P . c r$ & & 6.50 & & & 98.2 & 116.7 \\
\hline P. cristo & & 4.40 & 324 & & 109.0 & 89.8 \\
\hline P. djelfer & & 6.60 & 275 & & 100.0 & 68.0 \\
\hline P. djelfe & & & 367 & & & 109.0 \\
\hline P. ele & 4.8 & 6.40 & 438.0 & 216 & 121.8 & 124.0 \\
\hline P. elephas M (7) & 4 & 5.04 & 361.8 & 140.9 & 96.8 & 75.0 \\
\hline P. saharae F (6) & & 5.75 & 347 & & 102.6 & 86.3 \\
\hline P. sahara & 4.25 & 4.25 & 217.5 & 139.8 & 100.0 & 105.3 \\
\hline T. cisti $\mathrm{F}(5$ & & 6.42 & 160 & & 78.8 & 60.0 \\
\hline & & & 170.8 & & 72.0 & 72.5 \\
\hline T. pulchripennis $\mathrm{F}$ (5) & & 7.15 & 152.7 & 113.8 & 99.5 & 88.0 \\
\hline T. pulchripennis $\mathrm{M}$ (5) & 3.74 & 3.34 & 164.0 & 122.2 & 70.6 & 69.0 \\
\hline
\end{tabular}

TABLE 5. Residuals of the regressions of the number of sensilla against labrum width. $\mathrm{M}$ - male; $\mathrm{F}$ - female.

\begin{tabular}{lrrrrr}
\hline Species & \multicolumn{1}{c}{ resid } & \multicolumn{1}{c}{ resid } & \multicolumn{1}{c}{ resid } & \multicolumn{1}{c}{ resid } & \multicolumn{1}{l}{ mean } \\
& \multicolumn{1}{c}{ A1 } & \multicolumn{1}{c}{ A2 } & \multicolumn{1}{c}{ A3 } & \multicolumn{1}{c}{ A10 } & \\
\hline O. volxemii $\mathrm{F}$ & -90.77 & -20.28 & -15.27 & -5.82 & -33.04 \\
O. volxemii $\mathrm{M}$ & -34.12 & -36.39 & -12.84 & -8.70 & -23.01 \\
P. auresianus $\mathrm{F}$ & 25.26 & -2.51 & 7.55 & -7.17 & 5.78 \\
P. auresianus $\mathrm{M}$ & 53.65 & 41.98 & 15.48 & 22.98 & 33.52 \\
P. batnensis $\mathrm{F}$ & 77.49 & 16.52 & 17.75 & 9.56 & 30.33 \\
P. batnensis $\mathrm{M}$ & 80.30 & 30.46 & 11.14 & -13.51 & 27.10 \\
P. cristatus $\mathrm{F}$ & 102.96 & 18.12 & -13.35 & 22.77 & 32.62 \\
P. cristatus $\mathrm{M}$ & 77.13 & 21.64 & 20.96 & 6.57 & 31.57 \\
P. djelfensis $\mathrm{M}$ & 79.20 & 27.91 & 16.82 & 20.97 & 36.23 \\
P. elephas $\mathrm{F}$ & 104.28 & 63.90 & 11.32 & 30.61 & 52.53 \\
P. elephas $\mathrm{M}$ & 86.79 & 2.01 & 1.59 & -11.46 & 19.73 \\
P. saharae $\mathrm{F}$ & 41.29 & 21.18 & -0.66 & -3.85 & 14.49 \\
P. saharae $\mathrm{M}$ & -23.21 & 8.74 & 13.63 & 22.92 & 5.52 \\
T. cisti $\mathrm{F}$ & -174.19 & -30.51 & -31.78 & -33.47 & -67.49 \\
T. cisti $\mathrm{M}$ & -49.58 & -14.11 & -9.10 & -7.51 & -20.08 \\
T. pulchripennis $\mathrm{F}$ & -213.50 & -45.68 & -19.32 & -9.21 & -71.93 \\
T. pulchripennis $\mathrm{M}$ & -37.35 & -0.01 & -5.58 & -8.77 & -12.92 \\
\hline & & & & &
\end{tabular}

based on its significant preference for consuming Poaceae. However, there was a greater diversity of plants in the faeces of $O$. volxemii than Tmethis and $P$. saharae.

In summary, we identified three different types of diet:

- Type 1: This diet includes generally less Poaceae and more Fabaceae than one would expect from their occurrence in the field (Pamphagus spp. and A. calabra). P. hystrix rhodanica could be related to this group.

- Type 2: This diet includes less Poaceae and fewer species (Tmethis spp. and P. saharae).

- Type 3: This diet includes more Poaceae and less Fabaceae $(O$. volxemii).

\section{Number of sensilla}

The greatest numbers of A1 sensilla were recorded in the genus Pamphagus, with often more than 400, at least in females (Table 4). The lowest numbers were recorded in Tmethis and Ocneridia, both with about 160. The greatest number of A2 sensilla was again recorded in Pamphagus, with about 170, whereas in Tmethis and Ocneridia there were around 110. The distribution between the species in terms of the numbers of A3 sensilla was similar, with 115 in Pamphagus and about 75 in Tmethis and Ocneridia. The variation in the numbers of

TABLE 6. Correlations between residuals. The Pearson coefficients are below the diagonal and the p-values above.

\begin{tabular}{lcccc}
\hline & Resid A1 & Resid A2 & Resid A3 & Resid 10 \\
\hline Resid A1 & & $2.8210^{-5}$ & 0.00049 & 0.0123 \\
Resid A2 & 0.836 & & 0.00038 & 0.0014 \\
Resid A3 & 0.752 & 0.761 & & 0.0075 \\
Resid A10 & 0.592 & 0.708 & 0.623 & \\
\hline
\end{tabular}



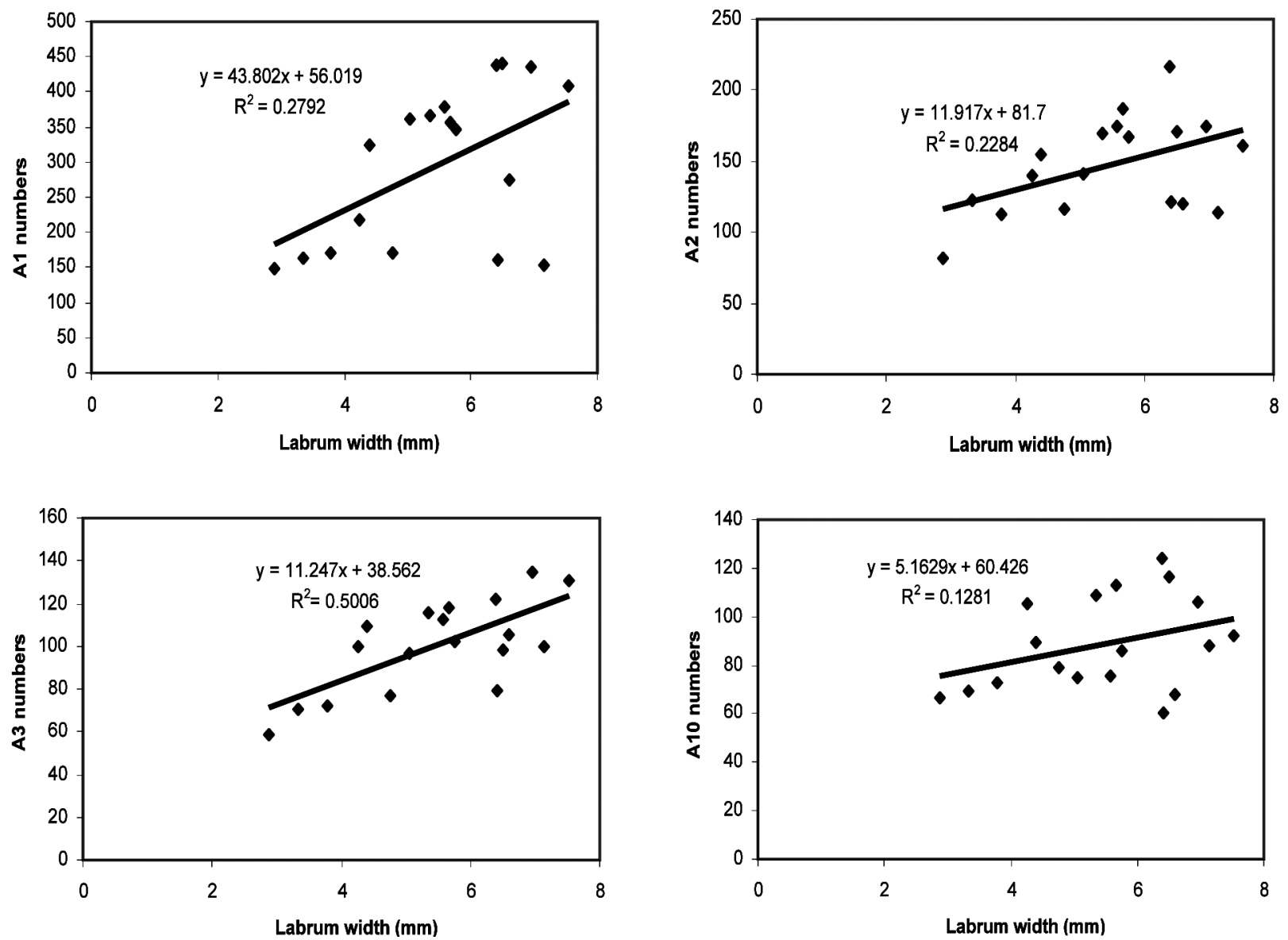

Fig. 4. Relationships between numbers of sensilla in groups A1 (A), A2 (B), A3 (C), and A10 (D) and width of the labrum.

A10 sensilla are more homogenous ranging from 60 (female $T$. cisti) to 124 (female P. elephas).

There is a relationship between labrum width and number of sensilla, at least for A1, A2, and A3 groups of sensilla. The regression equations and plots are presented in Fig. 4. These equations were used to remove the effect of size by calculating the residuals (difference between observed and expected numbers of sensilla for a given labrum width). Most residuals for A1, A2 and A3 sensilla are positive in Pamphagus and negative in Tmethis and Ocneridia (Table 5). The residuals for $P$. saharae are either positive or negative dependent on the group of sensilla and sex. Thus, we determined whether the residuals for the different groups of sensilla were significantly correlated (Table 6).

TABLE 7. Diets of genera of grasshoppers belonging to three subfamilies.

\begin{tabular}{lcc}
\hline Subfamilies & Genera & Diet \\
\hline \multirow{3}{*}{ Pamphaginae } & Pamphagus & Forbivore \\
& $\begin{array}{c}\text { Paracinipe } \\
\text { Ocneridia }\end{array}$ & Ambivore \\
& Acinipe & Forbivore \\
\hline Orchaminae & Tmethis & Ambivore \\
\hline \multirow{2}{*}{ Prionotropisinae } & Prionotropis & Ambivore \\
\hline
\end{tabular}

\section{Relationships between the different types of diet and the number of sensilla}

ANOVA was carried out to determine whether the number of sensilla was associated with the type of diet the grasshoppers consumed. In order to remove the effect of the size of the labrum, we treated the sensilla residuals as dependent variables and type of diet as factors.

In the case of the A1 residuals (Fig. 5A), there is a significant difference between the diets $\left(\mathrm{Fr}_{2,14}=12.31, \mathrm{p}=\right.$ 0.001 ) and Tukey post hoc test indicates that the highest values were recorded for the type 1 diet. In contrast, the values for the type 2 and 3 diets are not significantly different. The same result was recorded for A2 $\left(\mathrm{Fr}_{2,14}=7.48\right.$, $\mathrm{p}=0.006)$ and $\mathrm{A} 3$ residuals $\left(\mathrm{Fr}_{2,14}=5.79, \mathrm{p}=0.015\right)$ (Fig. $5 \mathrm{~B}$ and $\mathrm{C}$, respectively) and the A10 residuals did not

TABLE 8. The results of the analysis of covariance of the association between the numbers of sensilla in the different groups of sensilla, labrum width of the males of the 18 species studied and grasshopper family. Only the p-values are indicated.

\begin{tabular}{ccc}
\hline $\mathrm{n}=18$ & Labrum width & Family \\
\hline $\mathrm{A} 1$ & $<0.001$ & 0.958 \\
$\mathrm{~A} 2$ & $<0.001$ & 0.828 \\
$\mathrm{~A} 3$ & $<0.001$ & 0.673 \\
$\mathrm{~A} 10$ & 0.003 & 0.007 \\
\hline
\end{tabular}



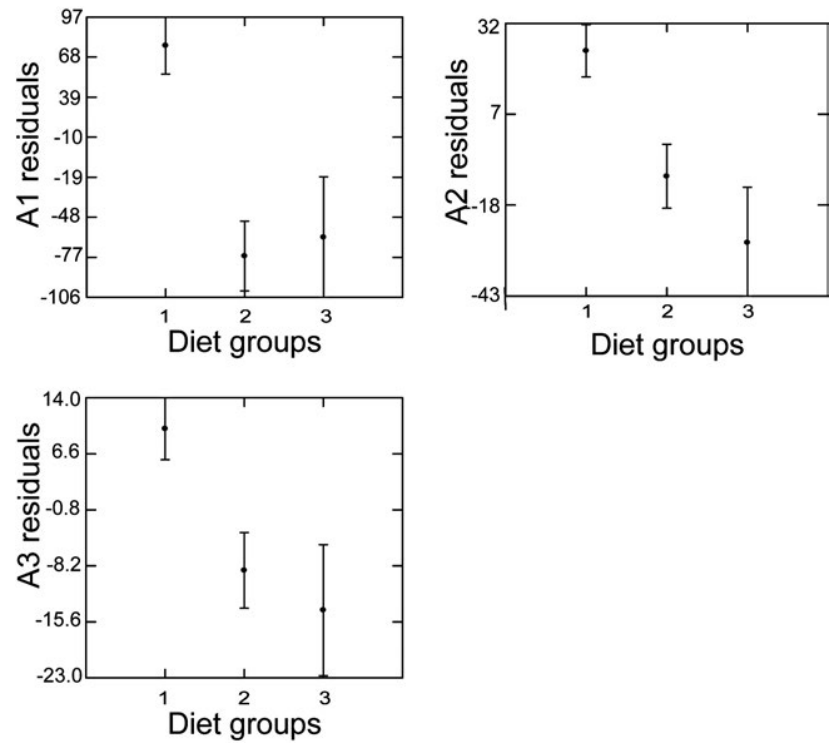

Fig. 5. Variations in the residuals of the numbers of sensilla recorded for grasshoppers of the 3 diet groups defined by cluster analysis presented in figure 3. ANOVA were done using SYSTAT 7.0. A - A1 sensilla; B - A2 sensilla; $\mathrm{C}-\mathrm{A} 3$ sensilla.

differ significantly between diets $\left(\mathrm{Fr}_{2,14}=1.955, \mathrm{p}=\right.$ $0.18)$.

\section{DISCUSSION AND CONCLUSION}

The diet of the Pamphagidae is poorly documented and this is the first study of the diet of several species belonging to several subfamilies of this family of grasshoppers. In addition, although the number of sensilla on the labrum of many groups of grasshoppers is well studied (Chapman \& Thomas, 1978) there are no studies of this sort on the family Pamphagidae.

All the species of Pamphagidae studied consume plants belonging to many plant families. However, the correlations between abundance of plants in the field and in the faeces of the grasshoppers studied were not significant, indicating that all these grasshoppers prefer to consume certain species of plant, as is the case in other Acridomorpha that are polyphagous, such as Schistocerca gregaria (Guendouz-Benrima et al., 2010) and Melanoplus sanguinipes (Uvarov, 1977). According to the last author, there are several types of grasshoppers, (i) forbivores (= herbivores), which feed predominantly on dicotyledonous plants, (ii) graminivores, which feed mainly on plants belonging to the family Poaceae, and (iii) ambivores, which feed on plants belonging both groups. In fact, there are very few species that are monophagous, i.e. they feed on a small number of plants species. For example in the paleotemperate region, there is Tropidopola cylindrica that only feeds on Phragmites australis in Algeria (Benkenana, 2006) and Glyptobothrus binotatus binotatus that feeds on Ulex spp in France (Picaud et al., 2002, 2003). Below we assign the types of diet we identified to those defined by Uvarov (1977). The type 1 diet (Pamphagus spp and Acinipe calabra) mainly consists of dicotyledonous plants and corresponds to that of a forbivore. The type 2 diet (Tmethis spp., Prionotropis hystrix
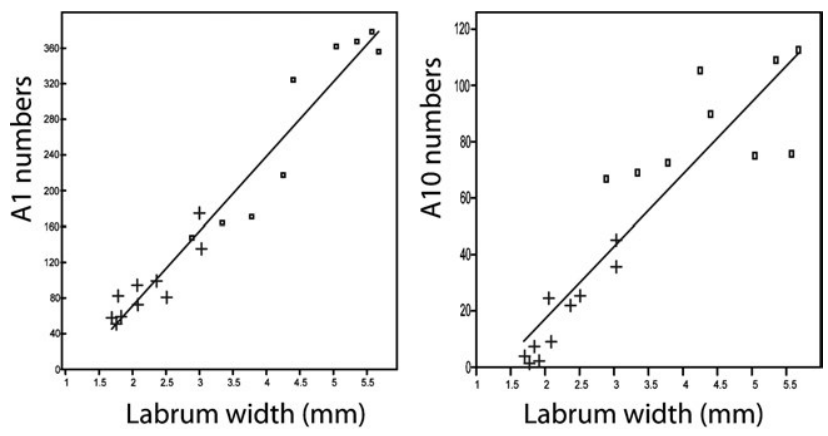

Fig. 6. Relationships between the numbers of sensilla and labrum size for Pamphagidae (squares) and Acrididae (crosses). A - A1 sensilla; B - A10 sensilla.

rhodanica and Paracinipe saharae) consists mainly of Poaceae and dicotyledonous plants and corresponds to that of an ambivore. The type 3 diet (Ocneridia volxemii) is similar to type 1 but contains less Fabaceae and is intermediate between that of an ambivore and graminivore. The preference of $O$. volxemii for Poaceae accounts for why this species is a serious pest of cereal crops (Bounechada \& Doumandji, 2003). The classification presented here based on faecal analyses should be tested by simple experiments on the feeding preferences of the grasshoppers, similar to those of Richards \& Waloff (1954) and Mulkern (1967). In addition, their requirements for particular nutrients (protein and carbohydrate content) also need to be studied as has been done for other grasshoppers by Simpson \& Raubenheimer (2001) and Raubenheimer \& Simpson (2003).

When several species of Pamphagidae coexist at the same locality, do they compete? In the case of the species in the Pamphagus gr. djelfensis complex we did not find any difference in the diets of the species. However, we have to consider competition in the context of their life cycle: in Eastern Algeria, larvae and adults occur in spring when the vegetation is lush and diverse and before the summer drought. At this time food is not a limiting factor for these species. The separation between the species is in their genetic and/or reproductive behaviour and not in their diets. This is the case for the two species of Tmethis. In addition, O. volxemii and Acinipe calabra do not compete because they prefer to consume different species of plants.

The diets of the grasshoppers in the genera studied are listed in Table 7. If the phylogenetic data are reliable it is likely that ambivory could be the ancestral diet of the family and then evolved towards forbivory in Pamphagus and Acinipe, and graminivory in Ocneridia. It is clear that investigations of other genera are needed to test this idea.

To compare the number of sensilla in the Acrididae we used the data for the males of most of the species studied by El Ghadraoui et al. (2002). This resulted in a dataset of 10 Acrididae with a clear range of different diets within each systematic group: 3 species belong to the Oedipodinae (Acrotylus insubricus, Oedipoda caerulescens and Stethophyma grossum), and 7 to Gomphocerinae (Dociostaurus maroccanus, D. genei, Chrysochraon dispar, 
Euchorthippus declivus, Chorthippus dorsatus, Chorthippus biguttulus and C. binotatus binotatus). When the numbers of sensilla are plotted against labrum width (Fig. 6A for A1 sensilla) it appears that Pamphagidae have more sensilla and a larger labrum than the above Acrididae. Although the relationships between the numbers of sensilla in groups A1, A2 and A3 on labrums of different sizes in both families are similar, that for the number of sensilla in group A10 in the two families seems to differ as most dots for the species of Pamphagidae are above the regression line (Fig. 6B). The covariance analysis in which the number of sensilla was treated as a dependent variable, labrum width a covariate and family a group revealed that the numbers of sensilla in groups A1, A2 and A3 do not differ in these two families when the effect of the variation in the size of the labrum is corrected for (Table $8, \mathrm{p}>0.6$ ). However, there is a significant difference in the number of sensilla in group A10 in these two families $(p=0.007)$. We interpret the low number of sensilla in group A10 in most Gomphocerinae and some Oedipodinae as a result of their mainly being graminivores and that grasses contain low amounts of secondary metabolites (Chapman \& Joern, 1990).

The chemical compounds present in plant leaves are identified by specific sensilla of insects. Several sensilla on the antenna identify olfactory cues (Chen et al., 2003; Dumas et al., 2010). However, the sensilla on the labrum are involved in sensing the taste of the juice that exudes from crushed leaves. Forbivore species (Pamphagus spp.) have more sensilla in groups A1, A2 and A3 than ambivore species, which might indicate that those species that are graminivores have fewer sensilla because there is a lower content of secondary metabolites in grasses than dicotyledonous plants (Dumas et al., 2010). The lower number of sensilla in group A10 is only revealed when polyphagous species (Pamphagidae) are compared with graminivores (Acrididae). These conclusions are supported by experiments on Schistocerca gregaria: Haskell \& Mordue (1969) showed that A3 sensilla are sensitive to deterrent molecules, such as azadirachtin, and A1 and A2 to those stimulating feeding, such as sucrose.

As the life cycle of Pamphagidae in Algeria is mostly restricted to a short period in spring, we hypothesize that a polyphagous diet enables them to maximize their consumption of food. This is supported by the biology of Dociostaurus maroccanus (Acrididae: Gomphocerinae), which progressively feeds on a wider range of plant species, including dicotyledonous plants, as the vegetation gradually dries out (Benhalima et al., 1984).

ACKNOWLEDGEMENTS. We thank A. Foucart of CIRAD for providing faeces of Prionotropis rhodanica, K. Heu for her help with the microscopy and F. Vallet of the University of Limoges for her technical assistance. Authors have no conflict of interest to declare. This work was funded by the program Tassili $n^{\circ}$ 08 MDU726.

\section{REFERENCES}

Benhalima T., Gillon Y. \& Louveaux A. 1984: Utilisation des ressources trophiques par Dociostaurus maroccanus (Thun- derg, 1815) (Orthoptera, Acrididae). Choix des espèces consommées en fonction de leur valeur nutritive. - Acta. Oecol., Oecol. Gen. 5: 383-406.

BENKENANA N. 2006: Etude biosystématique et quelques aspects bio-écologiques des espèces acridiennes d'importance économique de la région de Constantine. Thesis, Université Mentouri, Constantine, $196 \mathrm{pp}$.

Benkenana N., Harrat A. \& Petit D. 2012: The Pamphagidae (Orthoptera) from East Algeria and description of a new species. - Zootaxa 3168: 22-38.

Benzara A., Doumandul-Mitiche B., Doumandis S.E. \& Touati M. 1993: Régime alimentaire du genre Calliptamus (Serville, 1831) (Orthoptera, Acrididae) sur le littoral oriental algérois. - Mededel. Fac. Landb. Univ. Gent 58: 339-345.

Biond M. \& MAssa B. 1995: Le specie nordafricane e italiane del genere Acinipe (Orthoptera Pamphagidae). - Fragm. Entom. 27: 61-115.

Bounechada M. \& DoumandiI S.E. 2003: Research on Ocneridia volxemi Bol. (Pamphagidae, Orthoptera) in Setifian high plains (North-Eastern of Algeria). Eighth Arab Congress of Plant Protection, 12-16 October 2003. El-Beida, Libya, p. 24.

Butet A. 1985: Méthode d'étude du régime alimentaire d'un rongeur polyphage (Apodemus sylvaticus L., 1758) par l'analyse microscopique des fèces. - Mammalia 49: 455-483.

Chapman R.F. \& Joern A. 1990: The chemoreceptors. In Chapman R.F. \& Joern A. (eds): Biology of Grasshoppers. John Wiley \& Sons, New York, 563 pp.

Chapman R.R \& Thomas J.H. 1978: The numbers and distribution of sensilla on the mouthparts of Acridoidea. - Acrida 7: 115-148.

Chen H.H., Zhao Y.X. \& Kang L. 2003: Antennal sensilla of grasshoppers (Orthoptera: Acrididae) in relation to food preferences and habits. - J. Biosci. 28: 743-752.

Chopard L. 1943: Orthoptérö̈des de l'Afrique du Nord. Librairie Larose, Paris, 450 pp.

ClaRKE K.R. 1993: Non-parametric multivariate analysis of changes in community structure. - Austr. J. Ecol. 18: 117-143.

Descamps M. \& Mounassif M. 1972: Le complexe Orchamus, Paracinipe, Acinipe et Pamphagus (Acridomorpha Pamphagidae). - Acrida 1: 247-303.

Dumas P., Tetreau G. \& Petit D. 2010: Why certain male grasshoppers have clubbed antennae? $-C$. R. Biol. 333: 429-437.

Dutoit T., Buisson E., Fadda S., Henry F., Coiffait-Gombault C. \& Jaunatre R. 2011: Dix années de recherche dans une pseudo-steppe méditerranéeenne: impacts des changements d'usage et restauration écologique. - Sécheresse 22: 75-85.

Eades D.C., Otte D., Cigliano M.M. \& Braun H. 2011: Orthoptera Species File Online. Version 2.0/4.0. Available from http://Orthoptera.SpeciesFile.org/ April, 2011.

El Ghadraoui L., Petit D., Picaud F. \& El Yamani J. 2002: Relationship between labrum sensilla number in the moroccan locust Dociostaurus maroccanus and the nature of its diet. J. Orth. Res. 11: 11-18.

Gangwere S.K. \& Morales-Agacino E. 1973: Food selection and feeding behavior in Iberian Orthopteroidea. - An. Inst. Nacl. Invest. Agr. (Prot. Veg.) 3: 251-337.

Guendouz-Benrima A., Duranton J.F. \& Doumandi-Mitiche B. 2010: Préférences alimentaires de Schistocerca gregaria (Forsk., 1775) à l'état solitaire dans les biotopes du Sud Algérien. - J. Orth. Res. 19: 7-14.

Hammer D.A.T., Harper P.D. \& Ryan P.A.S. 2001: Paleontological statistics software package for education and data 
analysis, Palaeont. Electr. 4 (9) http://palaeoelectronica.org/ 2001 1/past/issue 1 01.htm.

Haskell T.P. \& Mordue A.J. 1969: The role of mouthpart receptors in the feeding behaviour of Schistocerca gregaria. - Entomol. Exp. Appl. 12: 591-610.

Idowua A.B., EdemaA M.O. \& Oyedepoa M.T. 2009: Extracellular enzyme production by microflora from the gut region of the variegated grasshopper Zonocerus variegatus (Orthoptera: Pyrgomorphidae). - Int. J. Trop. Insect Sci. 29: 229-235.

Ihsan S. \& Donskoff M. 1988: Catalogue et clés de détermination illustrés des Pamphagidae du Proche Orient (Orth.). Bull. Soc. Entom. Fr. 93: 13-31.

Isely F.B. 1944. Correlation between mandibular morphology and food specificity in grasshoppers. - Ann. Entomol. Soc. Am. 37: 47-67.

Ladrón de Guevara R.G., Pavón Bentto J. \& Presa J.J. 2009: Outbreak of Acinipe deceptoria (Bolívar, 1878) and Acinipe segurensis (Bolívar, 1908) (Orthoptera: Pamphagidae) in Castilla-La Mancha (Iberian Peninsula). - An. Biol. 31 33-35.

LaunOIs-Luong M.H. 1975: Méthode d'étude dans la nature du régime alimentaire du criquet migrateur Locusta migratoria capita (Sauss). - Ann. Zool. Ecol. Anim. (Paris) 8(1): 25-32.

Massa B. 1992: Due nuove specie di Pamphagus Thunberg dell'Algeria e Marocco (Orthoptera, Pamphagidae). - Frust Entomol. (Pisa) 13: 199-212.

Massa B. 1996: Le specie del genere Paracinipe Descamps \& Mounacif del gruppo zebrata (Brunner) (Insecta, Orthoptera Pamphagidae). - Natural. Sicil. 20: 71-97.

Massa B. \& Biondi M. 1987: Le specie del genere Ocneridia Bolivar 1912 (Orthoptera, Pamphagidae). - Ann. Soc. Entom. Fr. 23: 169-174.

Massa B. \& Cusimano G. 1979: Note sulla biologia e l'accrescimento di Pamphagus marmoratus Burm. e P. sardeus (Herrich-Schaeffer) (Insecta, Orthoptera). - Natural. Sicil. 3: 27-38.

Massa B. \& Lo Verde G. 1990: Ciclo biologico delle specie del genere Pamphagus Thunberg 1815 (Orthoptera, Pamphagidae). - Frust. Entomol. (n.s.) 13: 213-224.

Massa B., Lo Valvo M. \& Lo Verde G. 1993: Le specie del genere Pamphagus Thunberg 1815 (Orthoptera, Pamphagidae). - Mus. Reg. Sci. Nat. (Turin) 11: 445-467.

Moussi A., Abba A., Harrat A. \& Petit D. 2011: Desert acridian fauna (Orthoptera, Acridomorpha): comparison between steppic and oasian habitats in Algeria. - C. R. Biol. 334: $158-167$.
MulKern G.B 1967: Food selection by grasshoppers. - Аnnu. Rev. Entomol. 12: 59-78.

Picaud F., Gloaguen V. \& Petit D. 2002: Mechanistic aspects to the feeding preferences in Chorthippus binotatus (Acrididae, Gomphocerinae). - J. Insect Behav. 15: 513-526.

Picaud F., Bonnet E., Gloaguen V. \& Petit D. 2003: Decision making for food choice by grasshoppers (Orthoptera, Acrididae): comparison between a specialist species on a shrubby legume and three graminivorous species. - Environ. Entomol. 32: 680-585.

Ould Elhadj M.D. 2001: Etude du régime alimentaire de cinq espèces d'Acridiens dans les conditions naturelles de la cuvette de Ouargla (Algérie). - Sci. Technol. 16: 73-80.

QuÉzel P. \& SANTA S. 1962-1963: Nouvelle flore de l'Algérie et des régions désertiques méridionales. Vol. 1, 2. CNRS, Paris, $566+1170 \mathrm{pp}$.

RaUbenheimer D. \& Simpson S.J. 2003: Nutrient balancing in grasshoppers: behavioural and physiological correlates of dietary breadth. - J. Exp. Biol. 206: 1669-1681.

RichaRDS O.W. \& WALOFF N. 1954: Studies on the biology and population dynamics of British grasshoppers. - Anti-Locust Bull. 17: 1-182.

Rizzo M.C. \& Massa B. 1995. Morfologia mandibolare degli Ortotteri in relazione alla posizione trofica. - Phytophaga $\mathbf{6}$ : 209-222.

Simpson S.J. \& Raubenheimer D. 2001: The geometric analysis of nutrient-allelochemical interactions: a case study using locusts. - Ecology 82: 422-439.

SPSS INC. 1997: SYSTAT ver. 7, The System for Statistics. Inc, Evanston, IL.

Thomas J.G. 1966: The sense organs on the mouthparts of the desert locust (Schistocerca gregaria). - J. Zool. (London) 148: $420-448$.

Uvarov B.P. 1943: The tribe Thrinchini of the subfamily Pamphaginae, and the interrelations of the acridid subfamilies (Orthoptera). - Trans. R. Entomol. Soc. (London) 93: $1-72$.

Uvarov B.P. 1977: Grasshoppers and Locusts. Vol 2. Centre for Overseas Pest Research, Cambridge University Press, Cambridge, $613 \mathrm{pp}$.

Zhang D., Li X., Wang W., Yin H., Yin Z. \& Yin X. 2005: Molecular phylogeny of some genera of Pamphagidae (Acridoidea, Orthoptera) from China based on mitochondrial 16S rDNA sequences. - Zootaxa 1103: 41-49.

Received July 31, 2012; revised and accepted December 5, 2012 